\title{
Mycobacterium uberis Infection in the Subcutaneous Tissue of the Radius/Ulna Area of a Cow
}

\author{
Lorraine Michelet* (D) and Maria Laura Boschiroli $(\mathbb{D}$ \\ Laboratory for Animal Health, Tuberculosis National Reference Laboratory, ANSES, University Paris-Est, \\ 94700 Maisons-Alfort, France; maria-laura.boschiroli@anses.fr \\ * Correspondence: Lorraine.michelet@anses.fr
}

Received: 16 October 2020; Accepted: 30 October 2020; Published: 30 October 2020

\begin{abstract}
Mycobacterium uberis (M. uberis) is a recently described non-tuberculous mycobacterium phylogenetically close to Mycobacterium leprae (M. leprae) and Mycobacterium lepromatosis (M. lepromatosis). This pathogen classically causes nodular thelitis in cattle and goats. Here, we discuss what seems to be the first described case of M. uberis infection in a novel anatomical site, in the proximal or distal position (information not available) of the radius/ulna area of a cow. As this case was discovered in the framework of bovine tuberculosis (bTB) surveillance program in France, this type of infection could interfere with the screening and diagnostic tools employed for bTB.
\end{abstract}

Keywords: Mycobacterium uberis; M. leprae-like mycobacterium; radius/ulna area; cattle; bovine tuberculosis; diagnosis; interference

\section{Introduction}

The genus Mycobacterium is a large genus that encompasses over 200 officially described species [1]. Except for the Mycobacterium tuberculosis complex (MTBC) and M. leprae, which are intracellular bacteria, mycobacteria are considered saprophytic and commonly found in the environment such as soil, water, and sediments [2]. Non-tuberculous mycobacteria (NTM) pose two main problems for animal and human public health: they are potentially responsible of opportunistic infections for humans and animals leading to significant economic losses and they can interfere in the diagnosis of bovine tuberculosis and other major mycobacterioses [3].

Mycobacterium uberis is a recently described mycobacterium, genetically close to the leprosy-causing bacilli Mycobacterium leprae and Mycobacterium lepromatosis [4]. Leprosy, due to M. leprae and M. lepromatosis, was considered as a disease of humans; however, it has been described in several animal hosts, including armadillos, red squirrels and non-human primates [5]. Eurasian red squirrels are currently the only known wild rodents carrying the leprosy bacilli and are considered a reservoir for leprosy in the British Isles [6,7]. M. uberis has been described as the causative agent of nodular thelitis in dairy animals $[8,9]$. Nodular thelitis due to this mycobacterium was originally described in France affecting cows $[10,11]$. The clinical manifestation of this pathology is the occurrence of chronic skin teat lesion with three stages: (1) localized inflammation, (2) oedema and spreading inflammation and (3) ulceration [11]. The use of next generation sequencing of the mycobacterium's genomic DNA extracted directly from animal lesions made possible the description of this non-cultivable pathogen. Indeed, all attempts to grow the agent responsible for nodular thelitis in artificial media have failed $[8,9,11]$ - a common trait shared with M. leprae due to their highly reduced genomes [4].

Bovine tuberculosis (bTB) caused by Mycobacterium bovis is a transmissible notifiable disease whose prevalence in cattle herds in Europe has been increasing in spite of long lasting and costly control campaigns [12-14]. France was declared officially bTB free in 2001 by the EU; however, M. bovis infection is frequent in cattle and wildlife, in particular in the Nouvelle-Aquitaine region [15]. 
The surveillance system in France is based on the ante mortem screening (single intradermal cervical test (SICT), single intradermal cervical comparative test (SICCT) and the Interferon gamma test (IFN- $\gamma$ )) in cattle [16]. Diagnosis of bTB, as recommended by the EU, is based on bacteriology, histology and in France also by PCR. The case presented was discovered in the framework of the annual bTB screening test.

\section{Case Report}

A four year old "Prim'Holstein" cow was slaughtered in March 2019, as part of the bTB surveillance program in France, after a suspected positive result with the stringent interpretation of $\operatorname{SICCT}(\triangle \mathrm{PPDb}-\triangle \mathrm{PPDa}=1.2 \mathrm{~mm}$ and $\Delta \mathrm{PPDb} \geq 2.4 \mathrm{~mm})$. This cow belonged to a dairy herd, from the Pyrénées-Atlantiques department, in South-west France (Nouvelle-Aquitaine region).

Veterinary inspection at the slaughterhouse revealed a subcutaneous lesion at the left anterior radius/ulna area, suggesting actinomycose or tuberculosis. Samples of the lesion as well as lymph nodes targeted for bTB diagnosis (retropharyngeal, tracheobronchial, mediastinal and mesenteric) were first submitted to first-line bTB diagnosis (bacteriology/PCR and histopathology) by authorised regional laboratories (RL) of the bTB national surveillance network [17]. Briefly, histopathology was based on Hematoxylin-Eosine and Ziehl Neelsen staining. DNA extraction was performed after mechanical lysis using an LSI MagVetTM Universal Isolation Kit (Life Technologies) with a KingFisherTM Flex automate (Thermo Scientific), following the manufacturer's instructions. The LSI VetMAX ${ }^{\mathrm{TM}}$ MTBC Real-Time PCR kit (Life Technologies), which targets IS6110, is used for MTBC detection. Bacterial culture was performed following the protocol established by the French national reference laboratory (NF U 47-104) for isolation of M. bovis. Amounts of 2 to $5 \mathrm{~g}$ of sampled tissues were crushed with a $4 \%$ sulfuric acid solution to decontaminate the tissue. After $10 \mathrm{~min}$, the acid was neutralised by adding a $6 \%$ sodium hydroxide solution. After decontamination, the supernatant was seeded on two different media: Löwenstein-Jensen and Coletsos. All seeded media were incubated at $37{ }^{\circ} \mathrm{C}+/-3^{\circ} \mathrm{C}$ for three months and examined every 2 weeks.

Histological changes consistent with mycobacteriosis were present in the subcutaneous lesion. There were large foci of necrosis surrounded by a granulomatous inflammation with multinucleated giant cells of the Langhans type. No acid fast bacilli were identified within lesions after Ziehl-Neelsen staining. DNAs extracted from the different samples (LN and cutaneous lesion) were all negative with MTBC PCR (Table 1). In case of positive histology and negative first line PCR-as for the cutaneous lesion-the DNA is sent to the national reference laboratory (NRL) for further characterization [18]. Identification of non-tuberculous mycobacteria species was performed at the NRL by sequencing the $65 \mathrm{kDa}$ heat shock protein gene (hsp65) [19]. The obtained sequences were compared to the GenBank/EMBL/DDBJ databases using the BLAST program. They showed 100\% identity with previously deposited M. uberis sequences (Genbank KJ095005 and KT599102) [8,9]. M. uberis was also confirmed using specific primers [4]. Bacteriological culture of this sample remained negative after three months.

Table 1. Summary of bovine tuberculosis (bTB) surveillance tests results.

\begin{tabular}{|c|c|c|c|c|}
\hline Sample & Bacteriology & Histopathology & MTBC PCR & Molecular Identification \\
\hline Retropharyngeal LN 1 & Negative & Negative & Negative & $\mathrm{NA}^{2}$ \\
\hline Mediastinal LN ${ }^{1}$ & Negative & Negative & Negative & $\mathrm{NA}^{2}$ \\
\hline Tracheobonchial LN ${ }^{1}$ & Negative & Negative & Negative & $\mathrm{NA}^{2}$ \\
\hline Mesenteric LN ${ }^{1}$ & Negative & Negative & Negative & $\mathrm{NA}^{2}$ \\
\hline Subcutaneous tissue & Negative & Positive & Negative & M. uberis \\
\hline
\end{tabular}

${ }^{1}$ LN: Lymph node, ${ }^{2}$ NA: not applicable. 


\section{Discussion}

This is the first description of M. uberis in the subcutaneous tissue of the radius/ulna area of a cow. Previously described sites of infection were mainly the udder or teat [8,9], but other locationsi.e., on the scrotum or on the flank-had also been described in goats [20]. To our knowledge, no other animal of this cattle herd showed cutaneous lesions or nodular thelitis. Previous studies suggest that milking operations may be implicated in infection transmission and that a greater occurrence of the disease is observed in 4-8 year-old cows or goats showing optimum milk production [10,20]. A wide range of clinical manifestations in humans and animals are caused by cutaneous mycobacterial infections, such as Buruli ulcer caused by M. ulcerans and other related slow growing mycobacteria, leprosy caused by $M$. leprae and $M$. lepromatosis, cutaneous manifestations of $M$. tuberculosis infection, and cutaneous infections caused by rapidly growing mycobacteria [21,22].

This is also the first description of M. uberis in the South of France (Table 2). Goat cases have been described in North-Western France $[8,20]$. Bovine cases have been described in the Jura and the Rhône departments, Eastern France $[9,11]$. The Pyrénées-Atlantiques region is currently among the most prevalent departments for bovine tuberculosis in cattle and in wildlife species (badgers and wild boar) in France [15]. This department gathers a third of the annual outbreaks. Screening tests are carried out on cattle every year in municipalities where at least one farm has been detected as an outbreak. As described in this article, M. uberis may interfere in the surveillance program of bTB, as non-specific reactions to the skin test, which have already been observed before [23], may occur. Additionally, the histological pattern observed in the cow lesion was compatible with tuberculosis. This case highlights the need of discriminating diagnostic tools such as molecular diagnosis that are demonstrated here to be a powerful method for differentiating non-tuberculous mycobacterioses from TB [18] to exclude any bTB suspicion. Bacteriology is not adapted for this bacterium due to its highly reduced genome. Indeed, attempts to cultivate mycobacteria from cows with nodular thelitis were unsuccessful [9].

Table 2. Comparison of the M. uberis cases identified in France.

\begin{tabular}{|c|c|c|c|}
\hline & Study 1 & Study 2 & Study 3 \\
\hline Year of discovery & 2013 & $2012-2013$ & 2019 \\
\hline French Region & Jura (North-east) & $\begin{array}{l}\text { Pays de la Loire } \\
\text { (Center) }\end{array}$ & $\begin{array}{l}\text { Nouvelle Aquitaine } \\
\text { (South-west) }\end{array}$ \\
\hline Host & Cow & Goat & Cow \\
\hline Type of herd & Dairy & Dairy & Dairy \\
\hline Size of the herd & 30 & 600 & 144 \\
\hline $\begin{array}{l}\text { Number of cases with } \\
\text { lesion }\end{array}$ & 10 & 100 & 1 \\
\hline Lesion Location & Teat & Udder/teat & Radius/ulna area \\
\hline Bacteriology & Negative & Negative & Negative \\
\hline Histology & $\begin{array}{l}\text { Granulomatous } \\
\text { dermatitis, necrosis }\end{array}$ & $\begin{array}{l}\text { Severe granulomatous } \\
\text { dermatitis, necrosis }\end{array}$ & $\begin{array}{l}\text { Granulomatous } \\
\text { inflammation, necrosis }\end{array}$ \\
\hline Ziehl Neelsen staining & Positive & Negative & Negative \\
\hline Diagnosis & Nodular thelitis & Nodular thelitis & $\begin{array}{l}\text { Subcutaneous } \\
\text { mycobacteriosis }\end{array}$ \\
\hline Molecular identification & M. uberis & M. uberis & M. uberis \\
\hline Reference & Pin et al., 2014 [9] & Chartier et al., 2016 [8] & This study \\
\hline
\end{tabular}

Author Contributions: Investigation, L.M. and M.L.B.; writing—original draft, L.M. and M.L.B.; writing一review and editing, L.M. and M.L.B. All authors have read and agreed to the published version of the manuscript.

Funding: This research received no external funding. The APC was funded by ANSES.

Acknowledgments: The authors thank the Pyrénées Atlantiques veterinary services.

Conflicts of Interest: The authors declare no conflict of interest. 


\section{References}

1. Tortoli, E. Microbiological features and clinical relevance of new species of the genus Mycobacterium. Clin. Microbiol. Rev. 2014, 27, 727-752. [CrossRef]

2. Falkinham, J.O., III. Environmental sources of nontuberculous mycobacteria. Clin. Chest. Med. 2015, 36, 35-41. [CrossRef] [PubMed]

3. Biet, F.; Boschiroli, M.L. Non-tuberculous mycobacterial infections of veterinary relevance. Res. Vet. Sci. 2014, 97 Suppl., S69-S77. [CrossRef] [PubMed]

4. Benjak, A.; Avanzi, C.; Benito, Y.; Breysse, F.; Chartier, C.; Boschiroli, M.L.; Fourichon, C.; Michelet, L.; Pin, D.; Flandrois, J.P.; et al. Highly Reduced Genome of the New Species Mycobacterium uberis, the Causative Agent of Nodular Thelitis and Tuberculoid Scrotitis in Livestock and a Close Relative of the Leprosy Bacilli. mSphere 2018, 3, e00405-18. [CrossRef]

5. Tio-Coma, M.; Sprong, H.; Kik, M.; van Dissel, J.T.; Han, X.Y.; Pieters, T.; Geluk, A. Lack of evidence for the presence of leprosy bacilli in red squirrels from North-West Europe. Transbound. Emerg. Dis. 2020, 67, 1032-1034. [CrossRef]

6. Ploemacher, T.; Faber, W.R.; Menke, H.; Rutten, V.; Pieters, T. Reservoirs and transmission routes of leprosy; A systematic review. PLoS Negl. Trop. Dis. 2020, 14, e0008276. [CrossRef]

7. Schilling, A.K.; Avanzi, C.; Ulrich, R.G.; Busso, P.; Pisanu, B.; Ferrari, N.; Romeo, C.; Mazzamuto, M.V.; McLuckie, J.; Shuttleworth, C.M.; et al. British Red Squirrels Remain the Only Known Wild Rodent Host for Leprosy Bacilli. Front. Vet. Sci. 2019, 6, 8. [CrossRef]

8. Chartier, C.; Albaric, O.; Cesbron, N.; Despres, J.; Hoogveld, C.; Michelet, L.; Boschiroli, M.L. Tuberculoid nodular thelitis in a dairy goat flock. Vet. J. 2016, 209, 199-200. [CrossRef]

9. Pin, D.; Guerin-Faublee, V.; Garreau, V.; Breysse, F.; Dumitrescu, O.; Flandrois, J.P.; Lina, G. Mycobacterium species related to M. leprae and M. lepromatosis from cows with bovine nodular thelitis. Emerg. Infect. Dis. 2014, 20, 2111-2114. [CrossRef]

10. Joubert, L.; Ferney, J.; Oudar, J.; Van, H. Thélite nodulaire tuberculoïde de la vache laitière à mycobactéries atypiques scotochromogènes. Rev. Med. Vet. 1963, 114, 87-105.

11. Thorel, M.-F. Bovine nodular thelitis: A clinicopathological study of 20 cases. Vet. Dermatol. 1990, 1, 165-170.

12. Getin-Poirier, V.; Crozet, G.; Gardon, S.; Dufour, B.; Riviere, J. Integrating data of veterinarians' practices in assessing the cost effectiveness of three components of the bovine tuberculosis surveillance system by intradermal tuberculin testing in French cattle farms through a scenario-tree approach. Res. Vet. Sci. 2020, 128, 242-260. [CrossRef] [PubMed]

13. de la Cruz, M.L.; Pozo, P.; Grau, A.; Nacar, J.; Bezos, J.; Perez, A.; Dominguez, L.; Saez, J.L.; Minguez, O.; de Juan, L.; et al. Assessment of the sensitivity of the bovine tuberculosis eradication program in a high prevalence region of Spain using scenario tree modeling. Prev. Vet. Med. 2019, 173, 104800. [CrossRef]

14. Allen, A.R.; Skuce, R.A.; Byrne, A.W. Bovine Tuberculosis in Britain and Ireland-A Perfect Storm? The Confluence of Potential Ecological and Epidemiological Impediments to Controlling a Chronic Infectious Disease. Front. Vet. Sci. 2018, 5, 109. [CrossRef]

15. Reveillaud, E.; Desvaux, S.; Boschiroli, M.L.; Hars, J.; Faure, E.; Fediaevsky, A.; Cavalerie, L.; Chevalier, F.; Jabert, P.; Poliak, S.; et al. Infection of Wildlife by Mycobacterium bovis in France Assessment Through a National Surveillance System, Sylvatub. Front. Vet. Sci. 2018, 5, 262. [CrossRef]

16. Delavenne, C.; Pandolfi, F.; Girard, S.; Réveillaud, E.; Jabert, P.; Boschiroli, L.; Dommergues, L.; Garapin, F.; Keck, N.; Martin, F.; et al. Bovine tuberculosis: Results and analysis of the epidemiological status of metropolitan France between 2015 and 2017. Bull. Epid. Santé Anim. Alim. 2020, 85.

17. Courcoul, A.; Moyen, J.L.; Brugere, L.; Faye, S.; Henault, S.; Gares, H.; Boschiroli, M.L. Estimation of sensitivity and specificity of bacteriology, histopathology and PCR for the confirmatory diagnosis of bovine tuberculosis using latent class analysis. PLoS ONE 2014, 9, e90334. [CrossRef]

18. Michelet, L.; de Cruz, K.; Karoui, C.; Tambosco, J.; Moyen, J.L.; Henault, S.; Boschiroli, M.L. Second line molecular diagnosis for bovine tuberculosis to improve diagnostic schemes. PLOS ONE 2018, 13, e0207614. [CrossRef]

19. Telenti, A.; Marchesi, F.; Balz, M.; Bally, F.; Bottger, E.C.; Bodmer, T. Rapid identification of mycobacteria to the species level by polymerase chain reaction and restriction enzyme analysis. J. Clin. Microbiol. 1993, 31, 175-178. 
20. Brentini, M.; Peroz, C.; Dagher, E.; Labrut, S.; Albaric, O.; Despres, J.; Tesson, C.; Bourreau, P.; Assie, S.; Michelet, L.; et al. Caprine nodular thelitis due to Mycobacterium uberis: A series of 26 cases in 11 dairy goat farms in Western France. Prev. Vet. Med. 2020, 181, 105060. [CrossRef]

21. Franco-Paredes, C.; Marcos, L.A.; Henao-Martinez, A.F.; Rodriguez-Morales, A.J.; Villamil-Gomez, W.E.; Gotuzzo, E.; Bonifaz, A. Cutaneous Mycobacterial Infections. Clin. Microbiol. Rev. 2018, 32. [CrossRef]

22. Gunn-Moore, D.A.; McFarland, S.E.; Brewer, J.I.; Crawshaw, T.R.; Clifton-Hadley, R.S.; Kovalik, M.; Shaw, D.J. Mycobacterial disease in cats in Great Britain: I. Culture results, geographical distribution and clinical presentation of 339 cases. J. Feline Med. Surg. 2011, 13, 934-944. [CrossRef] [PubMed]

23. Oudar, J.; Joubert, L.; Valette, L. Répercussion de la Thélite Nodulaire Mycobactérienne sur le Dépistage Allergique de la Tuberculose bovine; Société des Sciences Vétérinaires et de Médecine comparée de Lyon: Lyon, France, 1968; pp. 121-126.

Publisher's Note: MDPI stays neutral with regard to jurisdictional claims in published maps and institutional affiliations.

(C) 2020 by the authors. Licensee MDPI, Basel, Switzerland. This article is an open access article distributed under the terms and conditions of the Creative Commons Attribution (CC BY) license (http://creativecommons.org/licenses/by/4.0/). 